\title{
Evolution of Industrial Production and Economic Education in Russia
}

\author{
N.F. Tagirova ${ }^{1, *}$, E.I. Sumburova ${ }^{1}$ and Yu.A. Zherdeva $^{1}$ \\ *Corresponding authors: tag-nailya@yandex.ru \\ ${ }^{1}$ Samara State University of Economics, Samara, Russia
}

\begin{abstract}
The research considers evolution of industrial development and the educational policy of Russia of the first third of the 20th century. The authors investigate interrelation between processes of concentration of production, labor and professional education at the stage of the ending second technological "Large wave" (industrialization). The study purpose is to consider transformation of the system of higher business education as a social project of a new era - the era of mass production, mass labor and mass education. The research objectives are: to determine industrialization processes of production and society of Russia in 1890s-1930s, to define massification tools in the early Soviet epoch, to analyze experiments in the sphere of higher business education in Russia in 1918-1932. Research methodology consists of proceedings of Carlota Pérez and comparative historical analysis of industrial and educational changes. The main research results is justification of the "military-revolutionary" stage of industrialization in Russia, which was followed by social experiments in the sphere of higher business education that in the late twenties was replaced by "accelerated socialist" industrialization with mobilization planning and unidirectional specialized planned economic education.
\end{abstract}

Keywords: higher business education, XX century, Russia, technological revolutions, conception of «Large waves», massification.

\section{Introduction}

Creation of a training system of professional personnel in the economic sphere is a social result of the first technological revolutions. A higher educational institution plays a major public role at the key (focal) moments of the history. They act as "adapters" of technological changes (social and cultural function) and "drivers" of innovative and technological development (scientific and technical function and distribution of new knowledge).

The interrelation between technological progress and development of the educational system is indisputable; however, their mutual influence is not always observed. Economic historians are interested in industrial development in the context of economic growth, industrial (technological) revolution, its scientific and technical potential, market and administrative models, transformation of social and economic systems of countries, regions and the world in general. Historians of education investigate the dynamics, types, the structure of educational institutions, the principles and the methods in the context of the state educational and cultural policy.

The authors believe that the relevance of coordinated and combined studying of industrial evolution and the educational system is caused by modern reforms in the world educational system, which comes against a background of the fourth industrial revolution. As result of the third industrial revolution, the academic revolution [1] led to the mass nature of higher education and formation of knowledge economy. The fourth industrial revolution imposes other requirements for the educational system. The worthy response to this challenge is recombination of existing and operating institutions [2]. In this regard, studying of historical experience of development of a higher school at the stages of technological revolutions is an essential component of innovative breakthrough.

\section{Problem Statement}

Technological revolutions change a new industrial structure, where the leading positions are taken by branches, which did not exist earlier. At the same time, "rejuvenation" of old productions occurs on the basis of achievements of the corresponding technological reorganization. Industrialization changed all the components of production processes. Machine production is connection of an engine, transmission gear, working tool and energy. Nowadays labor should be taught for obtaining qualification. This multi-level and specialized production requires organization of space, equipment, workplaces etc. The science, which changes technical and economic paradigm in this period, is designed to be engaged in analysis and development of a certain sequence of actions (production technology), studying of cars and special materials [3]. Industrialization was followed by considerable increase in the volume of knowledge and development of scientific research [4]. It is not coincidentally that economic sociology, scientific organization of labor (SOL), the first projects of social engineering appeared at this stage [5,6]. Social changes are connected with active urbanization, growth of the level of general literacy, objective development process of a higher step of technical, economic education. Besides, the traditional way of rural life and mentality of peasants has changed in Russia. 
Frequently, all these processes, which are included the Large wave (C. Pérez), last about 5 decades. Researchers of the first industrial revolution also noted such duration [7-9].

\section{Research Questions}

Study of the problem in the scientific literature allows formulating the following questions:

- What was the evolution of industrial production in Russia in 1917-1928 like? Were there prerequisites for creation of a new educational social project in conditions of change of the political system at the stage of the second Large wave, the World War I, revolution, the Civil War and the period of rehabilitation?

- What were the novations in work of higher educational institutions in these conditions?

- What experiments were conducted in the educational system? Did the change of the technical and economic paradigm in the Soviet Russia take place? If yes, when did it happen?

The research hypothesis suggests that owing to external circumstances in Russia (burdens of the World War I and Civil Wars), historically established social and economic features at the stage of the second technological revolution (1890-1930), or the second Large wave, there was an objective need for social restructuring of the public. The Great Russian Revolution (1917-1922) was meant to be a kind of response to this requirement. Economic education became planned, social and economic, and only secondarily technical and economic.

\section{Purpose of the Study}

The purpose of the article is to consider the evolution of the system of higher business education in Russia in the first third of the 20th century as manifestation of industrialization (the second Large wave) and as a social project of a new era - the era of mass production, mass labor and mass education. Achievement of this purpose implies:

- analysis of evolution of industrial production and the Russian society of 1890s-1930s - massification of labor, production, education, social relations;

- determination of massification tools in the early Soviet epoch: state collectivization of production and capital, nationalization of education, militarization of labor and management, search for mechanisms of a new turn of industrialization;

- analysis of experiments in the sphere of higher economic education in Russia in 1918-1932.

\section{Research Methods}

The authors relies on the conception of "Large waves" of Carlota Pérez, who explains transformation of political and social institutions of regulation of the productive and economic sphere through the prism of change of the technological modes [10]. Technological changes in the society resulted in the "Large wave" of changes not only in economy, but also in other spheres. It is equally important that it is also manifested in changes on arrangement and management, and difficult socio-cultural and institutional motions. Socio-cultural changes are substantially caused by political changes. The system of business education is transformed under the influence of all these changes.

The research is based on archival documents and published sources: statutory and regulatory enactments and materials of periodicals. Study of decrees and resolutions of the Soviet government of 1918 - 1935 enabled to follow reforming of the higher educational system, which is carried out in the spirit of socialist ideology. Periodicals allowed identifying the main mechanisms and tools, which were used by the government for creation of a new model of higher education in the USSR. Regional features of economic education gave the chance to reconstruct the archive materials of Samara.

\section{Findings}

\subsection{Massification in Russia as a result of evolution of industrial production and the society (1890-1917)}

In conditions of development and complication of industrial production, labor inevitably became universal. Business and government searched for ways and mechanisms of effective mass management; however, they were of single nature. The war forced to look for mobilization mechanisms of army organization, military production, and society, which were applicable to a new situation. It provided the first experience of militarized mass management. By contrast with Germany, regulating processes in Russia did not become total. However, according to the last studies, procurement (requisition) of food for army, transport logistics, elements of military culture became a daily practice of the country [11-13]. The feature of Russia was the fact that the process of militarization of the society did not stop after the end of the World War I. The Civil war strengthened it; the Bolshevist management turned the state into a military camp. 
Consequently, the processes of massification of military, industrial and social spheres of public life in Russia began to manifest strongly in the period of the second Large technological wave.

As indicated by the calculations, made by contemporaries of the events, the development processes of the industry in the period of the World War I and the Revolution in general were not interrupted. L.B. Kafenhaus calculated the average annual data for 1887-1927. On its basis, he defined indexes of the physical volume of industrial output, which showed that according to the cost of gross output and to labor force in the heavy industry, there was an advancing growth in comparison with the general growth of the industrial and working index [14, p. 292-297].

The modern analysis of studies shows strengthening of interindustry disproportions, but also growth in the chemical industry, mechanical engineering and metal working [15]. An indirect confirmation of this fact is data of L.B. Kafenhaus on the cost of gross industrial output, growth of the average number of workers at one enterprise in the period of 1887-1927. For example, in the fuel industry from 76 to 2075 people, in the metal production from 122 to 456 people, in the textiles from 181 to 1632 people, in the chemicals from 18 to 3269 people, etc. [14, p. 298-317, 318-330]. The trends of concentration of production and labor force showed their stability for 40 years.

Manufacturing methods inevitably excluded former ideas about economic development; and it should have found reflection in economic education. During this period along with theoretical economic education, business schools on training managers appeared in higher education of the leading western countries [10,16-18]. At the same time, change of the technical and economic paradigm was not followed by change of social and economic perception of the world. The situation in Russia was different.

\subsection{Massification tools at the "military-revolutionary" stage of industrialization (1918 - 1924)}

Establishment of the Soviet higher school took place in conditions of birth of a new statehood and "democratization of education", which began in 1917 [19, p. 118]. Cardinal reorganization followed the path of massification, which was expressed in "proletarization" of higher school. In other words, it consisted in increase in natives of families of workers and the poorest peasantry. The government considered these population groups as their main social support.

Since August, 1918 higher education became free of charge; since October academic degrees and positions were reduced [20]. Teachers were divided into groups - professors giving lectures, and all others.

In conditions of the Civil war, economic crisis, hunger, budget deficit, and under unreasoned, precipitate personnel purges, higher school was on the brink of survival, however, its quantity increased. During this period, higher economic education was presented, firstly, by the former commercial institutions, transformed to Leningrad, Moscow, Kiev and Kharkiv Institutes of national economy; secondly, by economic departments of classical universities. For example, in 1920-1921 in Samara State University there was a social and economic department at the socio-historical faculty [21]. Thirdly, new practice-oriented institutes were created for the first time: for example, the industrial and economic institute was founded in Samara in 1921 [22]. However, this situation did not last for a long time.

In September, 1921 the decree of the Council of People's Commissars obliged economic enterprises to take educational institutions under patronage [23]. The same thing was discussed at the XI Congress of the Russian Communist Party (b) [24]. The party meeting on national education at the VIII Congress of Soviets supported the functional nature of higher schools. Each higher educational institution should turn out experts in some certain area [25]. The priority was given to specialization. As a result, higher educational institutions, which did not find financial support from enterprises or local government were closed or were transformed to technical colleges.

Consequently, at the "military-revolutionary" stage of industrialization in Russia, the Soviet power seeks to strengthen social support and at the same time to provide the Workers' and Peasants' youth with education. Expulsion of "old professorate" from higher educational institutions had purely political nature, but "bourgeois experts" still worked at factories, and scientists could make foreign scientific business trips. The government began to realize technical and economic requirements only in the end of the Civil war. At the same time, the government began to include higher educational institutions into production processes with the help of approved mobilization measures.

\subsection{Does "work force master equipment" or "equipment master work force"? (1925 - 1932)}

The Bolsheviks began to impose their own vision of prospects of construction of socialism on an industrial basis to science and society from the middle of the 1920s. At the XIV Congress of the Russian Communist Party (b) the idea about accelerated industrial development was suggested [26, p. 958-959]. Extermination of all objectors to the idea about accelerated industrialization and Stalin's understanding of industrial jump from "a zero cycle" began in the scientific and party environment. Political processes, «purges» of apparatus, replaced pluralism of ideas and opinions. Then there were mass repressions against bourgeois experts: Shahtinskoe delo in 1928, delo "Prompartii", "Trudovaya krestyanskaya partiya" etc. [27, 28]. L.B. Kafenhaus, whose statistical data is given above, was one of victims of delo "Prompartii". The first five-year industrial plan (1928-1932) was started. It cancelled calculations of the State Planning Committee of the USSR and implemented mobilization planning [29].

There were also fundamental changes in the training system. Since the late 1920s, only specialized higher educational institutions were opened. Prospects of a new technological cycle appeared in regions. For example, in the Middle Volga they were determined by open oil deposits. The structure of higher education has also changed in accordance with the changed regional economic structure. Consequently, Middle Volga pedagogical institute was opened in Samara in 1929, three technical institutes (mechanical, energetic, chemical and technological), Samara 
construction training school, Middle Volga regional medical institute were opened in 1930, Middle Volga planning institute was opened in 1931 .

In new economic conditions, there was no consensus about what higher education should be like. In 1929 after the November plenum of the Central Committee of the All-Union Communist Party of the Bolsheviks, training began to be identified with a production process. The All-Russian meeting of rectors in Moscow (January, 1930) considered an issue about introduction of polytechnical education. They expressed a wish "to release" a higher school from prerevolutionary traditions: "being multi-disciplinary and encyclopedic; isolation of theoretical training from production basis" [30, p. 98]. At the meeting it was decided to: introduce specialization from the first year of studying; eliminate a lot of subjects; use active training methods instead of lectures. Duration of training was 3-3, 5 years, test sessions and graduation theses were cancelled.

The "method of projects", which was adopted from the American school, became the main mode of study. According to this method, the student's group of 25-30 people consisted of crews of 3-5 people. In general, students began to treat a teacher as "a production worker" - a master, an instructor or a consultant [31, p. 111-112]. The variations of this method are "conveying and cyclic" and "brigade and laboratory". The educational process became an analog of production. In conditions of lack of educational literature, lack of individual responsibility, group knowledge evaluation of students, the method of projects led to sharp decrease in the level of specialist training. In 1931, the brigade and project method was cancelled and even forbidden in training practice by the resolution of the Central Committee of the All-Union Communist Party of the Bolsheviks.

In May, 1935 the Central Committee of the All-Union Communist Party of the Bolsheviks established a commission on a higher school, which was intended to prepare recommendations for improvement of work of higher educational institutions [19, p. 285]. Following its results, the Council of People's Commissars and the Central Committee of the All-Union Communist Party of the Bolsheviks established the resolution "About work of higher educational institutions and about management of higher school" in June 23, 1936. The resolution stated that in conditions of the socialism victory, when "the personnel, which mastered equipment, solve everything", "new, more strict requirements should be imposed on higher educational institutions, providing preparation of highly skilled, politically educated, erudite and cultural personnel", which are "capable to master the latest scientific achievements, to use the equipment to the bottom and to connect theory with practice in a Bolshevist way, to combine know-how with science" [32, p. 6].

Consequently, education kept social breadth at the "peaceful" industrialization stage, which is known as accelerated and Stalin's one. However, highly qualified scientific and technical personnel of a higher school were eliminated. Social engineering was manifested in change of ideological, economic and technical paradigm. The government set the task of mastering the equipment as a major one. Nevertheless, it turned the opposite side: in conditions of absence of the qualified management, lack of machines and equipment, high concentration of labor force made socialist industrialization large-scale, but technically one-sided. Currently, economic personnel were trained for the state planning governing bodies, but not for technical ones. It meant that social and economic, ideological and economic education was put to please the social project, but not the technological breakthrough.

\section{Conclusion}

Despite the military situation, mass education as a socially oriented project appeared in the Soviet Russia in 19181921. At this stage, it still kept different options of the future - classical commercial, university, professional and applied. Foreign experience was still studied, foreign scientific business trips were allowed, and bourgeois experts were involved.

By the middle of the 1920s, the situation in the country has significantly changed. The resurgent government laid down ambitious industrialization plans, cancelled pluralism of ideas and opinions, execrated and "refused services" of bourgeois experts. In fact, the Soviet accelerated industrialization was intended to finish the second Large wave of technological revolution. It changed the industrial structure, strengthened interindustry disproportions, but kept a high share of manual work. It could be expected that in the long term of the following wave this "postponed influence" of the second technological revolution (A. Maddison) will have inhibitory impact on it.

By the beginning of the 1930s, establishment of new higher educational institutions gained breadth. However, currently it is untenable: ideologically sustained, mainly applied, professional, and it is also considered as an analog of a production process. A classroom turned into a production shop, a higher educational institution changed into a plant. "Industrialization of education" became production of personnel, and economic education - production of planners.

\section{Acknowledgments}

This study thanks the support given by Russian Found for Basic Research (RFBR) and the Government of Samara Region to the project № 18-49-630008 "Experience of social design in the sphere of the higher economic education of the Samara region in the first half of the 20th century" 


\section{References}

1. P.G. Altbach, L. Reisberg, I. Froumin, (Eds.). Accelerated Universities. Ideas and Money Combine to Build Academic Excellence. Boston, Leiden: Brill (2018).

2. D.Stark, Geterarchy: asset ambiguity and organization of diversity in post-socialist countries. Economic Sociology, 2(2), 115-132 (2001). [in Rus.].

3. C. Pérez, Technological revolutions and techno-economic paradigms. Cambridge Journal of Economics, 34(1), 185202 (2009).

4. S.D. Bodrunov, The future. New industrial society: Reboot. Moscow: Cultural Revolution (2016). [in Rus.].

5. A.A. Bogdanov, Tectology. General Labor Organization. Berlin: Grzhebin Publishing House (1922). [in Rus.].

6. A.K. Gastev, How to work: A practical introduction to the science of labor management. $3^{\text {rd }}$ ed. Moscow: URSS, Librokom (2011). [in Rus.].

7. S. Broadberry, K.H. O'Rourke, The Cambridge Economic History of Modern Europe. Volume 2, 1870 to the Present. Cambridge: Cambridge University Press (2010).

8. P.Gregory, Economic growth of the Russian Empire (late XIX - early XX century.) New calculations and estimates. Moscow: ROSSPEN (2003). [in Rus.].

9. A. Maddison, Contours of the world economy, 1-2030 AD: Essays in macro-economic history. Oxford: Oxford University Press (2007).

10. A. Kaplan, European management and European business schools: Insights from the history of business schools. European Management Journal, 32(4), 529-534 (2014).

11. D. Beyrau, The concept and experience of total war (on the example of the Soviet Union). In I. Narsky (Ed.), Experience of world wars in the history of Russia: a collection of articles (pp. 28-48). Chelyabinsk: Stone Belt (2007). [in Rus.].

12. O.S. Porshneva, «The Mood of 1914»: Towards re-examination of the historiographical metaphor (Russia and the West). Bulletin of Peoples' Friendship University of Russia. Series: History of Russia, 2(12), 39-50 (2008). [in Rus.].

13. A.S. Senin, The Development of Transport System in Novorossia and Crimea on the eve and during the World War I. The New Historical Bulletin, 3(49), 61-77 (2016). [in Rus.].

14. L.B. Kafenhaus, The evolution of industrial production in Russia (the last third of the XIX century - the 30 s of XX century). Moscow: Epiphany (1994). [in Rus.].

15. A.S. Gruzinov, Economic collapse in 1917: the consequences of a long war or the result of the revolution? In Economic history. Annals 2016/17 (pp. 201-240). Moscow: Institute of Russian History (2017). [in Rus.].

16. R.P. Amdam, Business Education. In G.G. Jones \& J. Zeitlin (Eds.), The Oxford Handbook in business History (pp. 583-600). Oxford: Oxford University Press (2008).

17. L. Engwall, The anatomy of management education. Scandinavian Journal of Management, 23(1), 4-35 (2007).

18. R.R. Locke, The End of the Practical Man: Entrepreneurship and Higher Education in Germany, France, and Great Britain, 1880-1940. Greenwich, Connecticut: JAI Press Inc (1984).

19. E.I. Demidova, Historical experience and problems of Soviet high school reforming. Saratov: Publishing center of the Saratov state social and economic university (2006). [in Rus.].

20. Decree of Sovnarkom. Decree of Sovnarkom "About some changes in composition and structure of the state educational and higher educational institutions of the Russian Republic" 01.10.1918. In Code of justice and government decrees of 1917 - 1918 (pp. 999-1000). Moscow, Russia: Administrative office of Sovnarkom of the USSR (1942). [in Rus.].

21. Central state archive of Samara region, f. R-28, op. 1, d. 140, 1. 221 [in Rus.].

22. Commune, March 8, p. 2 (1921). [in Rus.].

23. Decree of Sovnarkom. Decree of Sovnarkom "About measures to improvement of supply of schools and other educational institutions" 15.09.1918. In Code of justice and government decrees of 1921 (pp. 796-797). Moscow, Russia: Administrative office of Sovnarkom of the USSR (1944). [in Rus.].

24. Commune, April 27, p. 4 (1922). [in Rus.].

25. Commune, August 31, p. 3 (1922). [in Rus.].

26. XIV Congress. XIV Congress of the All-Union Communist Party. Stenographic report. Moscow, Leningrad: State Publishing House (1926). [in Rus.].

27. J. Baberowski, Der rote Terror. Die Geschichte des Stalinismus. Munich: Deutsche Verlags-Anstalt (2003).

28. J. Plamper, The Stalin Cult: A Study in the Alchemy of Power. London: Yale University Press (2012).

29. O.N. Ken, Mobilization planning and political decisions (late 1920s - mid 1930s). $2^{\text {nd }}$ ed. Moscow: OGI (2008). [in Rus.].

30. V.G. Klevin, Road to the earth. (Sketches of history of the Samara agricultural institute). Samara, Russia: Samara agricultural institute (1994). [in Rus.].

31. K.L. Svechnikov, Method of projects in the history of the Soviet school. Kazan Pedagogical Magazine, 1, 109-115 (2007). [in Rus.].

32. Act of Sovnarkom. Act of Sovnarkom and Central Committee of the Communist Party "About work of higher educational institutions and about the management of the higher school" 23.06.1936. In The higher school: Main resolutions, orders and instructions. Moscow, Russia: Sov. nauka (1957). [in Rus.]. 